\title{
ENGLISH-INDONESIAN SLANG (ALAY): AN ETHNOGRAPHY STUDY
}

\author{
Okta Mahendra \\ Ahmad Dahlan University, Indonesia \\ Oktamahendra3@gmail.com
}

\begin{abstract}
English is absolutely crusial International language having function as one of global communication tools to connect one country to another countryOne can not be ignored that in Indonesia, English is not only International language but also expanding language influencing the citizens to mix Bahasa Indonesia and English as the slang.

Nowadays teenagers use Bahasa Indonesia slang adopted by English words, phrase, and terms. This looks at the society, especially teenagers and the transition from adolescence to adulthood (12 to 23 years). This phenomenon is actually very unique which they use some English words or phrases as their Alay slang language to communicate. It is such a case that should be researched by researcher and many people caring about Bahasa Indonesia and the way English insert in that slang. The cause and the use of it is the main case of that is actually the focus of research.

This study uses a qualitative approach design; ethnography research. A qualitative approach design using data derivedfrom documents. While the form of data collecting technique is content analysis of secondary text or visual material where the researcher analyzes the content of the documents grabbed, describe, interprete, determine the settings, last is report reflexively. The data is taken from documents; screenshot of conversations of subjects in Blackberry Messenger with several themes where the English-language Alay language is usually used ie the problem of romance and vacation.
\end{abstract}

Keywords: English- Indonesia slangs (Alay), ethnography research

\section{INTRODUCTION}

A : “ Lu jadi cewek kudu seterong ngapa! Apa- apa gak able. Kayak gue dong istriable banget. Jadinya gue kagak single"

B : "Woles woy. Gue lagi otewe jadi girl yang able, pelukable, cintaable, ciumable biar jadi istriable, which is gue cantik, banyak yang ngajakin taken gue. Gue kan anak hits yang OOTD banget."

In this modern era, technology developing very fast creates adaptating in some aspects such as fashion, culture, art, and language. One to be be focus of this study is language expantion where one language influences other language as the slang.

In Indonesia especially, language expantion is coming from English as the International Language. Citizens never realize it. This is influencing Bahasa Indonesia as the national unity language. One is truly proper because when we mirror English is global language avowed by United Nations. So in the fact, in Indonesia there are many English adopted words used as Indonesia national terminology. Well this is not a massive case because the adopted EnglishIndonesia words or terms are listed into Kamus Besar Bahasa Indonesia ( Indonesia National Dictionary), means they are proper to use for Indonesian as the national language standard. Now, when we look at the society especially teenagers aged 12 to 17, some English not officially include in Indonesia National Dictionary are used in their daily life as the slang where those are not like English slangs growing in the United Kingdom or United States of America, but those are slang Indonesia. They are popularly used in conversation betwen teenagers and their mates, in the school or outside school when they are hanging out, studying together, or even when they 
make a personal statues on their Facebook Account timeline, caption on their Instagram account, tweet on their tweeter, or live performance at Path. The EnglishIndonesia slangs used are awesomely unique where the teens combine Bahasa Indonesia and English, such as the suffix -able, they add on the Indonesia words. For istance, the word suami (husband) gets additional suffix -able to be suamiable, the word peluk (hug) is inserted suffix -able to be Pelukable. The additional suffix -able has meaning as bisa/ mampu (proper), so than the meaning of suamiable is a man that can be a husband candidate because of having criteria as the good husband, while pelukable is people comfortable to hug like a doll.

As the social phenomenon, Bahasa Indonesia used by teenagers is faster to develop than Bahasa Indonesia used by children or mature people. This is mirroring with the English- Bahasa Indonesia above noted as positive case where the teens try to think farer to use English meanwhile those are not in line with the English rules, structure or grammar but the researcher thinks that is acceptably well, as long as the goal of communication is reached.

\section{LITERATURE REVIEW}

When we discuss about the phenomenon, this adopting langugae EnglishIndonesia slangs can not be separated from the society, while society has connectioon with language; the development, use, change or even the existance. So it is extremely proper when the case teenagers using English-Indonesia slangs researcher connects to sociolinguistics theory. .

Sociolinguistics is the descriptive study of the effect of any and all aspects of society, including cultural norms, expectations, and context, on the way language is used, and the effects of language use on society. Sociolinguistics differs from sociology of language in that the focus of sociology of language is the effect of language on the society, while sociolinguistics focuses on the society's effect on language. Sociolinguistics overlaps to a considerable degree with pragmatics. It is historically closely related to linguistic anthropology and the distinction between the two fields has even been questioned. (Gumperz \& Cook-Gumperz, 2008).

Understanding language in society means that one also has to understand the social networks in which language is embedded. A social network is another way of describing a particular speech community in terms of relations between individual members in a community. A network could be loose or tight depending on how members interact with each other. For instance, an office or factory may be considered a tight community because all members interact with each other. A large course with $100+$ students would be a looser community because students may only interact with the instructor and maybe 1-2 other students. A multiplex community is one in which members have multiple relationships with each other. For instance, in some neighborhoods, members may live on the same street, work for the same employer and even intermarry. (Wardhaugh, 2006)

It is concluded sociolinguistics is defined as the study that is concerned with the relationship between language and the context in which it is used. In other words, it studies the relationship between language and society. It explains we people speak differently in different social contexts. It discusses the social functions of language and the ways it is used to convey social meaning. All of the topics provides a lot of information about the language works, as well as about the social relationships in a community, and the way people signal aspects of their social identity through their language. This study the relationship between language and society. They are interested in explaining why language and the ways it is used to 
convey social meaning. The study of social linguistic also focus on the language variation that emerge in the society. for example the way of how to speak of a group of student is different from the way of a group of bus drivers. Sociolinguistics is the study of the effect of any and all aspect of society, including culture norms and context, on the way language is used.

We can take a line that this English- Indonesia slangs phenomenon researched is a case of social and language in the term of sociolinguistics; Bahasa Indonesia collaborating English creates newest words, phrases, and terminologies then called as the newest Indonesia-English Slangs that never been used by some previous society groups.

\section{METHODS}

This study uses a qualitative approach design. A qualitative approach design using data derivedfrom documents. The purpose of qualitative research is to describe theempirical reality behind the phenomena imply a deep, detailed and complete. So theuse of qualitative approach in this research is to match the empirical reality with theprevailing theory by using descriptive method.

Qualitative research is best suited to address a research problem in which the researcher does not know the variables and need to explore. The literature might yield little information about the phenomenon of study, and the researcher needs to learn more from participants through exploration. For example, the literature may not adequately address the use of sign language in distance education courses. A qualitative research study is needed to explore this phenomenon from the perspective of distance education students. Unquestionably, using sign language in such courses is complex and may not have been examined in the prior literature. A central phenomenon is the key concept, idea, or process studied in qualitative research. Thus, the research problem of the difficulty in teaching children who are deaf requires both an exploration (because we need to better know how to teach these children) and an understanding (because of its complexity) of the process of teaching and learning (Creswell, 2012).

Spesifically, this research is included in Ethnography research in line with qualitative research approach design. Ethnographic designsare qualitative research procedures for describing, analyzing, and interpreting a culture-sharing group's shared patterns of behavior, beliefs, and language that develop over time. Central to this definition is culture. A culture is "everything having to do with human behavior and belief" (LeCompte, Preissle, \& Tesch, 1993, p. 5 as cited in Creswell. 2012). It can include language, rituals, economic and political structures, life stages, interactions, and communication styles. To understand the patterns of a culturesharing group, the ethnographer typically spends considerable time "in the field" interviewing, observing, and gathering documents about the group to understand their culture-sharing behaviors, beliefs, and language. (Creswell, 2012)

With the diverse approaches to ethnography identified in the realist, case study, and critical approaches, it is not easy to identify characteristics they have in common. However, for those learning about ethnographies, the following characteristics typically illustrate an ethnographic study; (1) cultural themes, (2) culture-sharing group, (3) shared patterns of behavior, belief, and language, (4) fieldwork. (5) Description, themes, and interpretation, (6) context or setting, (7) researcher reflexivity.

Researcher conducts an ethnography when the study of a group provides understanding of a larger issue. One also conducts an ethnography when the 
researher has a culture-sharing group to study — one that has been together for some time and has developed shared values, beliefs, and language. (Creswell, 2012).

The types of this ethnography research is Realist ethnography; an objective, scientifically written ethnography. A realist ethnography is an objective account of the situation, typically written in the third-person point of view, reporting objectively on the information learned from participants at a field site. In this ethnographic design:

a. The realist ethnographer narrates the study in a third-person dispassionate voice and reports on observations of participants and their views. The ethnographer does not offer personal refl ections in the research report and remains in the background as an omniscient reporter of the "facts."

b. The researcher reports objective data in a measured style uncontaminated by personal bias, political goals, and judgment. The researcher may provide mundane details of everyday life among the people studied. The ethnographer also uses standard categories for cultural description (e.g., family life, work life, social networks, and status systems).

c. The ethnographer produces the participants' views through closely edited quotations and has the final word on the interpretation and presentation of the culture (Van Maanen, 1988).

While the form of data collecting technique is content analysis of secondary text or visual material where the researcher analyzes the content of the documents grabbed, describe, theme, interprete, determine the settings, last is report reflexively. The data is taken from conversation with people, teenagers usually speaking English-Indonesia Alay, screeshots, then, analyze it about the aim and the meaning of the words, phrases used.

\section{FINDINGS AND DISCUSSION}

Data taken from documents; Screenshot of conversations with some subjects in contact Blackberry Messenger, namely MuhtarHadiPrayoga (19), Bebe (21), Virra (18) and Setia Rahayu (23). Researchers have a conversation with several themes where the English-language Alay language is usually used ie the problem of romance and vacation.

In the collection of documents and analysis, the researchers observed four conversations with different people, divided between the first conversation between MuhtarHadiPrayoga with the researchers, the second with Bebe and the researcher, the third conversation between Virra and the researchers and the fourth conversation between Setia Rahayu and the researchers. With enclosed transcript of conversation.

These conversations can be analyzed based on the theme and intent in the conversations made by both speakers while remaining in the ethnographic domain.

Analysis of the first conversation between MuhtarHadiPrayoga and researchers, found the words and terms analyzed in italics to facilitate the analysis. The words and terms indicated as the English-Indonesian Alay language are woles, OMG, ok fix, antimainstream, absurb, LOL, slug, ntap soul, PM, otewe, kepo, amazeng, freak, OOTD, followers, vroh, hits, sel, Follow, and follback.

The following is the intentional analysis of the English-Indonesian slangs (Alay) used by both speakers;

a. Woles derived from slow that from the English, slow which means slowly. 
b. OMG; Oh My God (English), is a term used to express admiration with the meaning of "Oh God"

c. Ok Fix; Okay if so.

d. Antimainstream; extraordinary. It is used to express things beyond the ordinary.

e. Absurb; not clear. The purpose of this word indicates that a person has doubts in doing something.

f. LOL; Is an abbreviation of the words in English "Laugh out Loud", which means to laugh out loud.

g. Seterong; actually comes from the English word Strong which means powerful. As in the English- Indonesia slang language, the use of the word Seterong is similar to the strong word.

h. Ntap Soul; The term is derived from the word ntap (English; mantap) and soul (English, soul). So, this term is defined as steady soul, or cool.

i. PM; Personal Message (English). The purpose of this term is a personal message as a status in Blackberry Messenger account.

j. Otewe; On The Way (English), Is an English-Indonesian slang shows that a person is on his way to a location to which he wants to go.

k. KEPO; Stands for the English word "Knowing Every Particular Object". That is people who want to know everything is more detail, all inquisitive.

1. Amazeng; A word derived from English that is amazing; extraordinary.

m. Freak; (Inggris). The word used to indicate that a person is nerd

n. OOTD;Out Of The Day (English). The term is categorized as an ENglish Indonesia slang taken from English to show someone who always follows the development of fashion .

o. Followers (Inggris), Is a word addressed to friends of followers in an Instagram account.

p. Vroh; bro/brother (English), This is a very popular word for peer calls with male sex.

q. Hits (English; swag), Is widely used by adolescents and adolescents to mature to label that someone is a swag and always follow the changes.

r. Follow (English), Word that is often used to ask someone to follow an Instagram account.

s. Follback; Following Back, a term in Instagram account to request or provide information to refollow an Instagram account.

In the second conversation between Bebe (21) and speakers, got some words and terms that are indicated as the English-Indonesian slang. Here is an analysis of the intent of the English-Indonesian slangs used by both speakers;

1. Istriable; Istri ( Indonesia), -able (affix in English). Istriable is a term consisting of two words namely wife in Indonesian, and suffix -able in English which means able / can. So, the purpose of the wife is a woman who has a personality worthy of being a candidate for a wife.

2. Which is (English), this term is used by alay to replace the word "yang" in Indonesian.

3. Instagramable (English; Things that are probably in the instagram account), ie the latest things that fit always follow the common developments in Instagram account.

4. Taken (English,This one is very familiar with alay speakers to invite someone to have a relationship. 
Furthermore, the following is the intentional analysis of the English-Indonesian slangs in the third conversation used by both speakers, between Virra and researchers. English-Indonesian Alay language is in italics. Not all are reanalyzed because there are several words that have been analyzed in the first conversation.

a. Sistah (English), This word is a word of vocation to a woman. The point of this calling term is not simply as a sister, but a friend.

b. Move on (English), As for this term is intended to express the desire to change further by thinking of new things that are more useful in the future.

The last is a conversational analysis between Setia Rahayu (23) and the researcher by using italics on terms that belong to the English-Indonesian Slangs ( Alay),

a. Suamiable; suami (Indonesian), -able ( English), the term suamiable consists of two languages ; English and Indonesian which combined into English-Indonesian slang (Alay) which means a man who can be a potential husband because it has the criteria like a good husband.

b. Nikahable; nikah (Indonesia), -able (English), someone who has good criteria to marry.

c. Ademable; adem (Indonesia), -able (English), someone who is so shinning.

\section{CONCLUSION}

The latest English-Indonesian slangs (Alay) is words and terms that is very popular among teenagers and teenagers to adolescence (12 to 23 years old) using English spoken simultaneously with Bahasa Indonesia. The terms and words used consist of the entire English or a combination of both are inserted in the Indonesian by adding suffix or prefix.

In this English-Indonesian Alay research, the researcher used qualitative methods in the realm of ethnography by connecting the elements of Language and the growing culture. Data collecting techn ique is done by collecting documents taken from conversation in BBM account with resource persons named MuhtarHadiPrayoga (19), Bebe (21), Virra (18), and Setia Rahayu (23).

Found some terms and words that are popular among certain people. The words and terms used have not been fully recognized as standard Indonesian listed in the Indonesian National Dictionary (Kamus Besar Bahasa Indonesia) or even official Oxford Dictionary, although some words or terms have equivalents.

\section{REFERENCES}

Anggara, Caesar. (2017). Kamus Gaul Terbaru Bahasa Anak Muda Kekinian. (Online). https://www.jatik.com/kamus-gaul-terbaru-bahasa-anak-mudakekinian/. Diakses pada 08 Juli 2017.

Creswell, J. W. (2012). Educational Research: Planning, Conducting, and Evaluating Quantitative and Qualitative Research (Fourth ed.). Boston: Pearson Education, Inc.

Gumperz, J. J., \& Cook-Gumperz, J. (2008). Studying Language, Culture, and Society: Sociolinguistics or Linguistic Anthropology? Journal of Sociolinguistics , 532-545. 


\section{APPENDICES OF CONVERSATION BETWEEN RESEARCHER AND THE OBJECTS OF RESEARCH}

Conversation below is a conversation between MuhtarHadiParayoga (19) as the first speaker and researcher as the second speaker through Blackberry Messenger.

"Anjirr maiih bocah, walaupun gua masih bocah, tetwp gua sayang dia. Elo ngapa nanyain tukang PHP? Mantan gua dia, elo suka sama dia? Tembak aja gan!"

"Bahahaaha, parah lu. Woles gan. Gua mah levelnya bidan lah yang hitz :D"

"Kagak main anak SMA. Wkwkwk"

"OMG? Bidan? Ane tau apa yang di cari ente? Wmmm Ok fix berarti bidan ya menarik :D (emoticon)"

"Anak SMA kan masih krinyis2 gimana gitu, antimainstream lah kalo pacaran sama anak SMA, apalagi kelas 2 masihan, kek adeknya Vroh. (emoticon) "

"Apalgi janda. Janda lebih menggoda. Hok a hok e"

" Dasar muka absurb. Lu mau pacaran, apa mau main adik- adikan? Main aja sama boneka, sekalian rumah- rumahan."

"LOL(emoticon) lagunya Cita Citata gan?"

"Bukan. Lagunya Emak Ijah"

"Absurb ngetsssss gannn"

"Makin Seterong lah ya pacran sama anak SMA. Kayak nyedot aura biar tetep muda. wkwkwkwk"

"Ya iya, antimainstream itu tadi, kan masih ABG alay2 gimana gitu kalo masih SMA"

"Ntap Soul"

"Ntaps raga gan, udah 2017 sekarang ganti"

"Itu PM otewe, mau OTW kemana gan? Packing segala"

"Sodara gua mau nikah gan, sama katingnya ente dulu. Mungkin ente kenal, mungkiun, eh gak tau juga deng. Ente kan orangnya freak tidak peduli dengan lingkungan sekitar"

"Parah gua peduli ya, siapa coba yang mungutin sampah depan lab? Sapa sih kepo sumpah gua"

"Kepo amat, amat aja gak kepo"

"Udah dulu gan, ane mau bersih rumah dolo. Ente bm'an sama ane nanti lama2 naksir kan amazeng"

"Afgan lu."

"Ebit gan ebit, freak lawakannya."

"yaudah. Buruan packing jangan lupa foto OOTD, tag biar semua followers lu vroh tau lu anak hits, kayak anak hits Instagram"

"Loh ane selebgram, tinggal dimana si lu cuy? Kok gak kenal gua"

"Oh@kebaldisakiti”

"Kebaltenandisakiti_follow aja ntar gua follback, selaw yay"

"Jijaay. Ogah"

"Sok gaya lu tong, freak ngets"

"Ahahahha. Followers gue udah $2 \mathrm{k}$ vroh :D"

"Oke uwes uwes, aku tak packing bro wkwk."

The second conversation is the conversation between the researcher as the first speaker with Bebe (21) as the second speaker.

"Duh istriable banget."

"ya elah bro (emoticon)" 
"Duh vete nih, ga able banget mau kemana- mana ga ada motor. Which is ane jomblo. Kemana ente?"

"Ane Cuma di rumah aja bro"

"Aduh anak hitswhich isInstagramable tapi di rumah aja? Duh"

"Hiah mau ya sih toi gak ada yg ajak taken"

Wkwkwkw. Pasang promo geh di Instagram. Biar ada yg ngajak taken."

"Haduh ane bingung deh kapan ane taken* which is me udah jomblo lama. Ane kurang apa coba?'

"Kurang tebel make up nya"

The third conversation below is the conversation between the researcher as the first speaker and Vira (18) as the second speaker.

"Kapn nih otewe kemana gitu, sistah?"

"Kapan aja bisa bossq"

"Nonton Festival Sekura di lampung Barat kuy?"

"Festival dalam rangka apa vroh? Hahahaa lollll. Kuy lah jadiin, kapan nehh?"

"Ya festival tahunan peringatan syawal"

"Single butuh hiburan, biar bisa foto, trus dipajang di IG, kasih captionOOTD kan

:D (emoticon)"

"Posisi di mana vroh? Okedehhh jgn smpe di cancel acara kita ya"

"Di rmah ini sistah. Oke fix jam 8 ane jemput ke rumah. Biar elu juga cepet move on dari para mantan yang yelah mencampakkan dikau. Wakakakak."

Percakapan terakhir adalah percakapan antara peneliti dengan kontak BBM bernama Setia Rahayu. Narasumber penelitian ini tergolong sebagai narasumber praremaja menuju dewasa dengan usia 23 tahun. Di bawah ini adalah transkrip percakapannya dengan tema percintaan.

"Alhamduillah suamiable lah ya. Nikahable. Ademable. "

"Hahahahahahahah. Ws mari rung to"

"Able lah ya. Uncch. Tapi kudu woles, jangan buru- buru. Biar nnti kalau kita nulis OTW itu beneran "OTW rewangan tempat mamak Setia" 